\title{
Feasibility Analysis of Small and Medium Enterprises of Shoes and Slippers in Bogor
}

\author{
O.V.B. Nainggolan * \\ Sekolah Tinggi Ilmu Ekonomi Wiyatamandala \\ Jakarta, Indonesia \\ * olivia.nainggolan@wiyatamandala.ac.id
}

\begin{abstract}
A feasibility analysis of Small Medium Enterprises (SME) of Shoes and Slippers in Bogor was held to get the depicture of the magnitude of investment and the costs spend for building the effort that gained by SME of Shoes and Slippers Entrepreneurs. The feasibility analysis including financial feasibility that committed to the SME business of shoes and Slippers that already exist was done to get the depicture of the magnitude that incurred and compared to the benefits that have been obtained and the description of cost benefit in the future by using SWOT. SWOT was used to answer the purpose of increasing the business of shoes and slippers in Pasir Eurih, Bogor. Based on the results, financial analysis was expected to be a reference of a SME of Shoes and Slippers in Bogor. The purpose of this study was to determine the feasibility of the SME of Shoes and Slippers in Bogor, also to determine the strategy pursued to develop the business to improve its competitiveness. The result of this research said that this was a proper business.
\end{abstract}

Keywords-Feasibility Analysis; Financial Feasibility; SWOT Analysis; SMEs

\section{INTRODUCTION}

Today, the economy of Indonesia shows less beneficial conditions for businesses and businesses doer. The high national inflation rate in the 2005 to 2014 which reached $8 \%$ and the issue of fuel price increases has become evidences of their lack country's economy condition. In these poor society conditions when prices needs basic commodities have increased and no longer affordable side by side with their offset by rising incomes.

However the previous experiences shows that SME's survive against waves of national crisis. [1] said wherever areas of people's economy are not just stretched but have been raised. SME is growing everywhere with independent funding or through funds of microfinance such as pawn shops, koperasi or informal institutions of microfinance in rural areas. Therefore, SME's need to be empowered to be able to develop in accordance with the growth needs of their community.

Investment analysis of SME's Shoes and Slippers in Bogor held to get an idea of the magnitude of the investment and the costs to be incurred in building the business and the amount of benefits to be gained by stakeholders of SME's Shoes and Slippers. The feasibility analysis including analysis of financial feasibility is committed to the SME business shoes and slippers that already exist today, to get an idea of the magnitude of the costs incurred and in comparison to the benefits that have been obtained and the description of a cost benefit in the future. Based on the results of the financial analysis is expected to be a reference to a financial analysis of SME's Shoes and Slippers in Bogor and The Loan Deposit Ratio is a commonly used as variable for assessing a bank or a financial institution's liquidity calculated by dividing the bank's total loans by its total deposits in rupiah and foreign currency. If the ratio is too high, it means that the bank may not have enough liquidity to cover any unforeseen fund requirements, and conversely, if the ratio is too low, the bank may not be earning as much as it could be. Important goal of the equation LDR is to find and assess how far the banks have a healthy condition in carrying out their operations. Previous research [2] found that liquidity bank is determinant essential in a bank loan in Turkey and monetary policy capable to manipulate position of the liquidity. Based on the provisions of Bank Indonesia, the Standard of Bank's Loan Deposit Ratio (LDR) according to Bank Indonesia is between $85 \%-100 \%$ (Bank Indonesia, 2015).

Table 1. Comparison LDR 2011 - 2015

\begin{tabular}{lccccc}
\hline $\begin{array}{l}\text { Total } \\
\text { Loans }\end{array}$ & $\mathbf{2 , 1 1 7}$ & $\mathbf{2 , 5 9 7}$ & $\mathbf{3 , 1 5 8}$ & $\mathbf{3 , 5 2 6}$ & $\mathbf{3 , 9 0 4}$ \\
\hline $\begin{array}{c}\text { Total } \\
\text { Deposits }\end{array}$ & 2,688 & 3,107 & 3,520 & 3,944 & 4,238 \\
\hline
\end{tabular}

The Table 1 above represents the changes of loan deposit ratios since 2011 - 2015, and makes it easier to understand the trends for each bank with respect to its peers. The growth of Loan to Deposit Ratio in Indonesia tend to slow down from 2011 to 2015, for about 14\%, which is indicated bigger challenge liquidity funds, and not in line with the growth of deposits which is $37 \%$ in five years. It means that people choose to divert their funds in deposits. This makes banking liquidity becomes excessive. The deposits has been collected is greater than the bank loans. This study uses fundamental analysis to examine the financial variables that have a significant influence in predicting loan deposit ratio in the Banking Companies Listed in Indonesia Stock Exchange.

Net loans to total asset ratio NLTA measures the percentage of assets that is tied up in loans. Net loan to total assets ratio (NLTA) is also another important ratio that measures the liquidity condition of the bank. Whereas Loan to Deposits is a ratio in which liquidity of the bank is measured in 


\section{RESULT}

terms of its deposits, NLTA measures liquidity of the bank in terms of its total assets. That is, it gauges the percentage of total assets the bank has investedin loans (or financings). The higher the ratio the less the liquidity is of the bank. Similar to LDR, the bank with low NLTA is also considered to be more liquid as compared to the bank with higher NLTA. However, high NLTA is an indication of potentially higher profitability and hence more risk. The higher the ratio, the less liquid the bank is.

In these poor society conditions, when basic commodity need prices have increased and are no longer affordable side by side with their offset by rising incomes. In general, a feasibility business study will be related to three aspects [3].:

1. Economic benefits to the business itself (also called as financial benefits), which means this business will be quite beneficial compared to its risk.

2. Economic benefits for the country where the business run. Social benefits for the people around the business

\section{METHOD}

This research used descriptive method. The unit of analysis observed was home industry and industry organization, and production costs and financial reports and sales reports from 2011 to 2015. The study was conducted in the area of SMEs Shoes and Slippers in the Desa Pasir Eurih, Tamansari, Bogor. The data collection was analyzed by several methods: Payback Period (PP), Net Present Value (NPV), Internal Rate of Return (IRR), Profitability Index (PI) and Net B / C and Break Even Point (BEP).

Requirement data consisted of primary data and secondary data. Primary data were obtained through questionnaires and were accompanied by using interviews of some subjects of the research. The research object of this study was SME's Shoes and Slippers in Pasir Eurih, so that all of the information obtained from these SME's compressed into this journal. The analysis technique used in this study were:

A. Technical Feasibility Analysis techniques, which include:

a) Analysis of Raw Materials;

b) Analysis of Human Resources;

c) Analysis of Road Infrastructure, and Electricity.

B. Economy and Social Feasibility Analysis, which included:
a) Increasing Government Wealthiness
b) The Employment Opportunities
c) Social

C. Financial Feasibility, which included:
a) Payback Period / Payback Method
b) Analysis Techniques NPV
c) Internal Rate of Return
d) Average Rate of Return
e) Profitability Index

D. SWOT
3.1 Technical feasibility:

Analysis of raw materials

Based on the interviews, it was found that the supply of goods craftsman shoe comes from a grocery store located around the workshops where craftsmen produce shoes.

Table 2. Analysis of raw material.

\begin{tabular}{ll}
\hline $\begin{array}{l}\text { Indicators of Rate } \\
\text { Raw Material }\end{array}$ & Value \\
\hline Quality & 3 \\
Accessibility & 4 \\
Price & 2 \\
Average Value & 3 \\
\hline
\end{tabular}

Analysis of human resources

Currently, SME Pasir Eurih has almost 30 craftsmen shoes and slippers and scattered around residential areas of Pasir Eurih.

\begin{tabular}{|c|c|}
\hline $\begin{array}{l}\text { Indicators of Human } \\
\text { Resources Assessment }\end{array}$ & Value \\
\hline Educational & 3 \\
\hline Skills & 4 \\
\hline Purchasing Power & 4 \\
\hline Average Value & 3,6 \\
\hline
\end{tabular}

Analysis of infrastructure, electricity, etc.

The technical feasibility analysis summary is shown below:

Table 4. Feasibility analysis.

\begin{tabular}{ll}
\hline $\begin{array}{l}\text { Technical Feasibility } \\
\text { Indicator }\end{array}$ & Value \\
\hline Raw & 3,6 \\
Human Resources & 3,6 \\
Infrastructure, & 4 \\
Electricity and Others & \\
\hline
\end{tabular}

3.2 Economy and Social Feasibility Analysis is shown below:

Table 5. Economy and social feasibility analysis.

\begin{tabular}{ll}
\hline $\begin{array}{l}\text { Indicators of Economy } \\
\text { and Social Feasibility }\end{array}$ & Value \\
\hline $\begin{array}{l}\text { Increasing Government } \\
\text { Wealthiness }\end{array}$ & 4 \\
$\begin{array}{l}\text { The Employment } \\
\text { Opportunities } \\
\text { Social }\end{array}$ & 4 \\
\hline
\end{tabular}

3.3 Analysis techniques of financial feasibility

The Technical Feasibility Analysis and Financial Feasibility summary is shown below:

Table 6. Economy and social feasibility analysis.

\begin{tabular}{ll}
\hline Financial Feasibility & Value \\
\hline Payback Period & 5 \\
Net Present Value & 5
\end{tabular}




\begin{tabular}{ll}
$\begin{array}{l}\text { Internal Rate of } \\
\text { Return }\end{array}$ & 5 \\
$\begin{array}{l}\text { Average Rate of } \\
\text { Return }\end{array}$ & 5 \\
Profitability Index & 1 \\
\hline
\end{tabular}

\subsection{SWOT}

Matrix strategy feasibility analysis of SME Shoes and Slippers based on SWOT analysis.

Table 7. SWOT Analysis.

\begin{tabular}{|c|c|c|}
\hline Factors & $\begin{array}{l}\text { Strategy } \\
\text { Strength }\end{array}$ & $\begin{array}{l}\text { Strategy } \\
\text { weakness }\end{array}$ \\
\hline \multirow{8}{*}{$\begin{array}{l}\text { Internal } \\
\text { Factors/ } \\
\text { External } \\
\text { Factors }\end{array}$} & Strengths (S) & Weaknesses (W) \\
\hline & $\begin{array}{l}\text { Unique and } \\
\text { creative products. }\end{array}$ & Capital limitation. \\
\hline & Competing Price. & $\begin{array}{l}\text { Cooperative } \\
\text { society stagnant. }\end{array}$ \\
\hline & $\begin{array}{l}\text { Production } \\
\text { Schedule. }\end{array}$ & $\begin{array}{l}\text { Unordered of } \\
\text { Administration } \\
\text { and Finance } \\
\text { Management. }\end{array}$ \\
\hline & Friendly people. & $\begin{array}{l}\text { Unordered of } \\
\text { inventory } \\
\text { management of } \\
\text { raw materials. }\end{array}$ \\
\hline & Accessibility raw. & $\begin{array}{l}\text { Less area and less } \\
\text { convenient land } \\
\text { work. }\end{array}$ \\
\hline & & $\begin{array}{l}\text { Minimal } \\
\text { technology }\end{array}$ \\
\hline & & Lack of employee. \\
\hline Opportunities & Strategy SO & Strategy WO \\
\hline $\begin{array}{l}\text { Potential } \\
\text { creative } \\
\text { cultural } \\
\text { Village }\end{array}$ & $\begin{array}{l}\text { There are } \\
\text { potentially } \\
\text { creative culture } \\
\text { villages that } \\
\text { desperately need } \\
\text { the creativity of } \\
\text { local people to } \\
\text { sell their region } \\
\text { products. Desa } \\
\text { Pasir Eurih } \\
\text { internally has had } \\
\text { a good } \\
\text { competence in the } \\
\text { production of } \\
\text { shoes and } \\
\text { Slippers. Besides } \\
\text { that, they also } \\
\text { have the creativity } \\
\text { and production } \\
\text { processes that } \\
\text { have been } \\
\text { operated long } \\
\text { enough. } \\
\text { Therefore, this } \\
\text { potential must be } \\
\text { cultivated and }\end{array}$ & $\begin{array}{l}\text { The local } \\
\text { government is } \\
\text { expected to } \\
\text { provide low } \\
\text { interest loan } \\
\text { facility which } \\
\text { aims to strengthen } \\
\text { the capital } \\
\text { structure of } \\
\text { SME's which are } \\
\text { underserved by } \\
\text { banks and other } \\
\text { financial } \\
\text { institutions. } \\
\text { Thus, the } \\
\text { craftsmen can be } \\
\text { independent and } \\
\text { run a better } \\
\text { business decision } \\
\text { making. Up to } \\
\text { now, business } \\
\text { decision still } \\
\text { depends on the } \\
\text { owners of capital. }\end{array}$ \\
\hline
\end{tabular}

enhanced.

Products are well By the existence Government aid known

of Creative

Cultural Village

can be used as a

facility to

introduce more

products Desa

Pasir Eurih shoes

and slippers to the

wider society.

Desa Pasir Eurih

already has a

market of

craftsmen shoes

and slippers in

Bogor. According

to researchers, a

greater

opportunity

should have been

open. The next

target is to sell

shoes and slippers

in a better way.

production

technology

development by

giving aid such as

big singer, sewing

machine, press

machine, emboss

machine, zigzag

machines, oven

machine, kun

machine, etc. By

utilizing the

technology in the

production

process, is able to

improve the

competitiveness

and quality of

goods produced.

The use of

technology is also

able to reach a

wider market due

to the increasing

production

capacity. So it can

be absorb orders

from various

parties.

Government

support

Strategic Place

Potential

Product

Diversification

\begin{tabular}{lll}
\hline Threats & Strategy ST & Strategy WT \\
\hline Internal and & Government & Local government
\end{tabular}

External strategy to cope provide low

Competitors

with external

competition is to

make import

restrictions

(quotas and rates)

and examine the

imported

products, learn

about the

production

process and

external product

technology and

also trains local

residents so that

local resident's

competence can

be increasing.

\begin{tabular}{lll}
\hline Threats & Strategy ST & Strategy WT \\
\hline Sales cycle & Utilization of & Network \\
\hline
\end{tabular}


Finance Management, Unordered of inventory management of raw materials, Less area and less convenient land work, Minimal technology, lack of employee.

External factors that strengthen of SME's shoes and slippers Desa Pasir Eurih are the potential development of rural tourism and proclaimed as creative cultural village, shoes and slippers are already well known, government support through training adds to the creativity of craftsmen, the strategic place to sell and spirit of creativity of the craftsmen provides the potential product diversification in developing businesses trend of shoes and slippers. The weakness of this business is the limited access to transportation facilities, internal and external competitors, the season, and purchasing power.

3. Based on the SWOT analysis, the strategies that can be executed by the craftsmen in order to develop SME business shoes and slippers in Desa Pasir Eurih is an increasing creativity in making many kind models of shoes and slippers for more diverse forms and styles, network optimization/ marketing channels through the development of cooperation with fellow craftsmen or employers and other marketers, expanding the network relationship marketing, the use of the website or e-mail as a way of promotion and marketing (development of ecommerce), to allocate funds from the sale to improve the production technology used, to cooperate in order to optimize the cooperation that has been established so it can be provided raw materials and working capital and be able to coordinate the distribution of the products, for the craftsmen work together to build collective power that can overlap or eliminate weaknesses.

4. One of strategies that can be used by the government in order to develop the SME business shoes and slippers in Desa Pasir Eurih is help craftsmen products by facilitating the new distribution channels. The government can also facilitate the craftsmen with training on financial management, business management and inventory management, the government give support the development of production technology. They can also assist craftsmen products by limiting imports of shoes and slippers, government facilitates the promotion of products at the deserted time of sale with their exhibitions, the government issued regulations and policies that support the improvement and development of the craftsmen production.

\section{REFERENCES}

[1] Mubyarto, 2003, Mengembangkan ekonomi rakyat sebagai landasan ekonomi pancasila, Jurnal Ekonomi Rakyat [artikel - th. Ii - no. 8 nopember 2003

[2] Alper, K. 2012. An Empirical Study on Liquidity and Bank Lending, Working Paper Turkiye Cumhuriyet Merkez Bankasi: 12/04.

[3] Husnan S. \& Suwarsono. 1995. Studi kelayakan proyek UPP. Yogyakarta: AM YKN. weakness was the lack of capital, the business enterprise (koperasi) is stagnant, Unordered of Administration and 